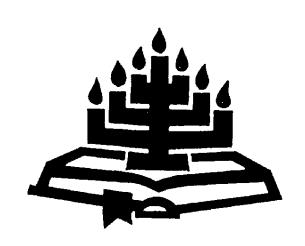

\title{
In die gastehuis van die prediking: preekvernuwing vanuit Bybelse en gereformeerde wortels
}

\author{
I.A. Nell \\ Departement Praktiese Teologie en Missiologie \\ Universiteit Stellenbosch \\ STELLENBOSCH \\ E-pos: ianell@sun.ac.za
}

\begin{abstract}
In the portals of preaching: renewal of preaching from within Biblical and reformed roots
\end{abstract}

The images of the mirror and the window offer useful perspectives when we consider renewal in public worship and preaching. This article focuses specifically on renewal in preaching. Are our sermons often simply a mirror reflecting what is happening in society? Shouldn't our sermons rather be a window offering new views, new perspectives on God and the world, that is views that can help us to live creatively and imaginatively in a time of tremendous challenges for the church and believers. This article investigates the metaphor of hospitality as a possible mechanism for renewal in preaching and helping us to see through the window.

\section{Opsomming}

In die gastehuis van die prediking: preekvernuwing vanuit Bybelse en gereformeerde wortels

Die beeld van die spieël en die venster bied 'n handige vertrekpunt wanneer oor vernuwing in die erediens en prediking nagedink word. In hierdie artikel is die aandag spesifiek op vernuwing van die prediking. Die vraag is of preke nie maar dikwels bloot 'n spieël is waarin ons ' $n$ refleksie vind van dit wat daagliks rondom ons in die samelewing aan die gang is nie. Daarmee saam is die vraag of die prediking nie eerder ' $n$ venster moet wees waardeur nuwe vergesigte oor God en sy wêreld oopges/uit behoort te word nie - vergesigte wat kan help om kreatief en verbeeldingryk te leef in ' $n$ tyd wat besondere uitdagings aan die kerk en aan gelowiges stel. In hierdie artikel 
word die metafoor van gasvryheid ondersoek as een moontlikheid in die soeke na vernuwing van die prediking.

\section{Inleiding}

Die beeld van die spieël en die venster bied 'n handige vertrekpunt wanneer daar oor vernuwing in die erediens en prediking nagedink word. In hierdie artikel val die fokus spesifiek op vernuwing van die prediking. Die vraag is of preke nie dikwels bloot 'n spieël is waarin ons 'n refleksie vind van dit wat daagliks rondom ons in die samelewing aan die gang is nie. Is preke 'n klompie vroom gedagtes wat mense moet help om in 'n wêreld te oorleef wat al groter eise aan hulle stel, of 'n individualisering en privatisering van godsdiens wat net te make het met my persoonlike verhouding met God, waar ek bloot my eie gesig in die spieël raaksien?

Die verdere vraag is of die prediking nie eerder ' $n$ venster moet wees waardeur daar nuwe vergesigte oor God en sy wêreld oopgesluit behoort te word nie - vergesigte wat mense help om kreatief en verbeeldingryk te leef in 'n tyd wat besondere uitdagings aan die kerk en aan gelowiges stel. In hierdie verband is die metafore wat vir die prediking gebruik word van belang, aangesien metafore kan help om hierdie vergesigte oop te sluit, maar dit kan ook in die weg daarvan staan.

In die veld van praktiese teologie word met vier basiese metodologiese vrae gewerk, naamlik: Wat is aan die gebeur? (deskriptiefempiriese taak); Hoe word dié data geïnterpreteer? (interpretatiewe taak); Wat behoort te gebeur? (normatiewe taak); Wat gaan gedoen word om dit te verander? (strategiese taak) (Osmer, 2008:4). Met hierdie basiese prakties-teologiese raamwerk in gedagte, word aan elkeen van die vrae aandag geskenk in die soeke na 'n nuwe metafoor vir die prediking en daarme saam na 'n verstelde praxis. Die navorser poog om aan elkeen van hierdie prakties-teologiese vrae aandag te skenk.

\section{Verbeelding en metafore}

Dit is duidelik dat die beeld van die venster hierbo bedoel is om ons "ver-beeld-ing" aan te gryp en ons wil help om oor nuwe moontlikhede vir die preek te droom. Dit is interessant om te sien hoeveel studies in die homiletiek die belang van verbeelding beklemtoon (vgl. Eslinger, 1995; Vos, 2002; Cilliers, 2002; 2004). 
By die sesde konferensie van die Internasionale Homiletiese Werkgemeenskap, wat in Doorn, Nederland, gedurende Junie 2001 plaasgevind het, was die tema "Preaching: creating perspective". Die klem het by hierdie konferensie geval op die prediking as kreatiewe daad wat verbeeldingryk nuwe wêrelde antisipeer.

Dit is redelik bekend dat metafore 'n belangrike hulpmiddel is om ons verbeelding te stimuleer en ons nuwe moontlikhede te laat antisipeer. Daarom is dit interessant om te bemerk hoe nuwe metafore in homiletiese navorsing die verbeelding stimuleer (vgl. byvoorbeeld Lowry, 1997; Engeman, 2001; Hilkert, 1997; Childers, 1998; Cilliers, 2002).

\section{Op soek na nuwe metafore}

In hierdie verband is dit dus noodsaaklik om voortdurend na nuwe metafore te soek om die homiletiese verbeelding te bly stimuleer. Metafore, as woorde wat binne 'n ongewone konteks gebruik word, help ons juis om nuwe insigte te gee.

Metafore is, in die woorde van Vos (2002:159) "plofstof wat mense tot nuwe insigte ruk en nuwe wêrelde oopskiet. Metafore stel skrywers in staat om die verrassende, die onopvallende, die skynbaar teensprekende en die ironiese te vind". Ricoeur (1979:27) herinner ons daaraan dat metafore tegelyk met die paradoks werk van dit is en is ook nie, waar die spanning in 'n metafoor terselfdertyd bevestig én ontken dat iets die geval is.

In McClure se boek (1995:29) maak hy van 'n interessante metafoor vir die prediking gebruik wanneer hy skryf:

The contemporary parish preacher could see the preaching ministry, at least in part, as an act of hospitality. The preacher is a host who welcomes to a roundtable strangers who bring various gifts into the community. (Kursivering - IAN.)

Hy ontwikkel egter nie die metafoor van gasvryheid verder nie, maar werk met die beeld van die "roundtable pulpit" wat op sigself 'n interessante en stimulerende bydrae is.

Toe die metafoor van gasvryheid my eie verbeelding begin stimuleer, was dit interessant om te sien watter navorsing reeds in hierdie verband gedoen is (vgl. Koenig, 1985; Keifert, 1992; Hendriks, 1999; Pohl, 1999; Vosloo, 2003; 2006). 
Myns insiens bied hierdie metafoor opwindende moontlikhede om vir die prediking te ontgin met die hoop dat dit verbeeldingryke nuwe perspektiewe kan open. Terselfdertyd moet Ricoeur (1979) se "metaforiese beperkings" in gedagte gehou word, naamlik dat metafore met die paradoks werk van dit is en is ook nie, om daarmee te sê dat ook hierdie metafoor nie die volheid van die prediking kan uitput nie.

\section{Vernuwing vanuit ons wortels}

Die subopskrif van hierdie artikel, "preekvernuwing vanuit Bybelse en gereformeerde wortels", het 'n dubbele betekenis: die metafoor van gasvryheid het Bybelse wortels, terwyl ons gereformeerde wortels ons ook help in die nadenke oor die verdere betekenis daarvan. Oor elkeen enkele opmerkings.

\subsection{Bybelse wortels}

\subsubsection{Gasvryheid in die algemeen}

Die Bybelse beelde van gasvryheid vind ons binne die breër sosiale konteks van die plig tot gasvryheid wat by verskillende kulture bestaan het (vgl. Ryken, 1998:402-404). Vir die Grieke was gasvryheid 'n teken van beskaafdheid, en die godsdienstige betekenis daarvan vind ons daarin dat hulle hoofgod, Zeus, 'n god van gasvryheid was. Vir die Egiptenare was gasvryheid 'n manier om 'n voorspoedige bestaan in die toekomstige lewe te verseker. Ook die Romeine het die gasvrye hantering van mense as 'n belangrike deug gesien.

Die sosiale konteks verklaar hierdie houdings jeens gasvryheid. Reis in die antieke Meditereense wêreld was vol gevare en spanning. Herberge of gastehuise waar water, voedsel en beskutting voorsien is, was min en ver uitmekaar. In Palestina is met verloop van tyd 'n kode van gasvryheid ontwikkel waardeur vreemdelinge verwelkom is en as vriende die gastehuis verlaat het in plaas van as vyande. Vir die gladde verloop van hierdie proses was dit belangrik dat elkeen sy/haar rol as gasheer, vreemdeling/gas en dienskneg moes vervul.

Die gasheer het die verantwoordelikheid gehad om water, kos en verblyf vir die gaste en hulle diere te voorsien (vgl. Gen. 24:23-25; 26:30; 33:1-33). Die gasheer was gewoonlik die manlike hoof van die huishouding, maar dit was dikwels ook vroue (vgl. 1 Kon. 17:10; 2 Kon. 4:8-10; Luk. 8:2-3). Vreemdelinge se aanvaarding as gaste is te kenne gegee deur hulle voete te was en aan hulle 'n maaltyd te 
voorsien (vgl. Gen. 18:4; 19:2; 24:32). Om nie die gaste te beledig en die eer van die gasheer aan te tas nie, moes die beste moontlike maaltyd voorgesit word. Verdere eer kon aan die gaste betoon word deur hulle hoofde met olie te salf en aan hulle 'n ereplek aan die tafel te gee. Dit was ook die plig van die gasheer om die gas se lewe te beskerm.

Die vertrek van die gas was die laaste fase in die siklus van gasvryheid. Volgens gebruik kon die gaste van 'n huishouding verwag om aan hulle verblyf (vir nie meer as twee nagte nie) te verskaf. Die doel van die finale fase was dat die gas in vrede kon vertrek sonder om die sosiale harmonie van die huishouding of die gemeenskap omver te werp.

\subsubsection{Buitengewone gasvryheid as Israel se mandaat}

Dit is belangrik om in die Ou Testament raak te sien hoe God wil hê dat sy uitverkore volk hulle geestelike en morele verbond met Hom moet beskerm deur die deug van gasvryheid (vgl. Ryken et al., 1998:403). Terwyl al die mense van die antieke Nabye Ooste die deug van gasvryheid beoefen het, het Israel hulle deelname aan dié deug verstaan in die lig van hulle unieke geskiedenis as deel van die volk van God. Hulle tradisionele voorvader, Abraham, was 'n vreemdeling, en verhale van die reisende patriarge, die Israeliete wat "resident aliens" in Egipte was en wandelende vreemdelinge in die woestyn dien as arge- of prototipes. In Deuteronomium 10:17-19 staan: "Die Here jou God, Hy alleen is God ... Hy laat reg geskied aan die weeskind en die weduwee. Hy het die vreemdeling lief en gee vir hom kos en klere. Jy moet ook die vreemdelinge liefhê, want jy was self 'n vreemdeling in Egipte."

Dit is ook interessant om te sien hoe God se voorsiening vir Israel in die Ou Testament dikwels die kwaliteite van menslike gasvryheid aanneem. God was die volk Israel se gasheer in die woestyn deur water, voedsel en beskerming te voorsien (vgl. Eks. 15:24-25). Hy het hulle as 't ware gesif voor hulle intog (vgl. Num. 14:21-24). Hy het hulle uitgenooi om in die land Kanaän te woon en het 'n plek van oorvloed voorberei (vgl. Lev. 25:23; vgl. ook die bespreking onder die "Groot Gasheer" in 6.2).

\subsubsection{Die kerk as huis van gasvryheid}

Soos in die Ou Testament vind 'n mens ook in die Nuwe Testament 'n groot aantal verwysings na gasvryheid (vgl. Vosloo, 2002; Ryken, 1998:404). Die verhaal van Jesus se lewe as 'n rondreisende rabbi 
en wonderwerker is in 'n sekere sin 'n chronologiese weergawe van die gasvryheid wat Hy geniet het (vgl. Matt. 26:6; Mark. 1:29; 7:24; 14:3; Luk. 7:36; 14:1; Joh. 12:1-2). Volgens Vosloo (2002) vind ons die spesifieke fundering vir gasvryheid in die Nuwe Testament as die vrug van geloof in Jesus Christus.

Twee tekste in die Nuwe Testament speel 'n belangrike rol in die verstaan van Christelike gasvryheid, naamlik die gelykenis van die maaltyd in Lukas 14:15-24 en die gedeelte oor die laaste oordeel in Matteus 25:31-46. Oor hierdie twee teksgedeeltes lewer Vosloo (2006:73) soos volg kommentaar:

Die gelykenis van die maaltyd, waarin die armes, die kreupels, die blindes en die verlamdes genooi word, beeld iets uit van God se universele welkom - ook aan hulle wat deur die samelewing gemarginaliseer word. Hierin sien ons iets van die vreemde ekonomie van God se koninkryk. In Matteus 25 word die aksent gelê dat die wat vreemdelinge ontvang, Christus ontvang. lets van hierdie aksent weerklink ook in die oproep tot gasvryheid in Hebreërs 13 vers 2. Die aksent van gasvryheid in die gelykenisse in byvoorbeeld die Lukas-evangelie teken God as 'n gasvrye, barmhartige en vrygewige God. (Vgl. ook Luk. 15:23 e.v.)

Soortgelyke beelde van gasvryheid vind ons ook op verskeie ander plekke in die Nuwe Testament en besonderlik in die verhaal van die Vroeë Kerk (Hand. 2:46). Gasvryheid was 'n sleuteldeug in die missionêre aktiwiteite van die Vroeë Kerk. Ons vind die bewyse daarvan in die lewe en werk van Petrus (Hand. 10:6) en Paulus (Hand. 16:15), wat albei op gasvryheid van kontakte staatgemaak het in hulle omswerwings. Daarom vind ons ook oproepe tot die gelowiges om dit te beoefen (Rom. 12:13; 1 Pet. 4:9; 1 Tim. 3:2; Tit. 1:8; vgl. ook Ryken, 1998:404).

\subsubsection{Die koninkryk: finale gasvryheid}

Die koninkryk van God word in die Nuwe Testament aan ons voorgehou as dié plekke en tye waar God se behoefte aan en belofte van onbedorwe gasvryheid vervul sal word deur 'n eindelose fees. In 'n interessante omkeer van rolle aan die begin van die boek Openbaring, word die individu wat antwoord op die roepstem van Jesus as die gasheer voorgestel, met Christus as die gas wat Homself genooi het en by die deur staan: "Kyk, Ek staan by die deur en Ek klop. As iemand my stem hoor en die deur oopmaak, sal Ek by hom ingaan en saam met hom 'n feesmaal hou, en hy saam met My." (Op. 3:20.) 
In Openbaring 19:7-9 word diegene wat in die hemel is, uitgebeeld as gaste by die huweliksfees van die Lam, terwyl Openbaring eindig met 'n finale uitnodiging: "Die Gees en die bruid sê: 'Kom!' En elkeen wat dit hoor, moet sê: 'Kom!' En elkeen wat dors het, moet kom; elkeen wat die water van die lewe wil hê, moet dit kom kry, verniet!" (Op. 22:17.)

\subsection{Gereformeerde wortels}

Verskeie stemme pleit daarvoor dat, wanneer daar oor vernuwing van die kerk, die erediens en die prediking gedink word, ons ook deeglik rekening moet hou met ons eie gereformeerde tradisie. Leith (1990:82-114) praat van "the renewal of the church according to its own theology and practice", wat 'n vernuwing voorstel vanuit die wortels van die gereformeerde tradisie, met die vernuwing van die prediking as 'n aparte hoofstuk. Wanneer Wainwright (1991:45) skryf oor vernuwing in die erediens, gaan hy selfs verder terug en praat van "renewing worship: the recovery of classical patterns".

Burger (2001) wys op die belofte wat die vyf sentrale motiewe agter die gereformeerde tradisie inhou wanneer ons nadink oor kerk-, erediens- en preekvernuwing. In die bespreking wat volg, sal sowel die Bybelse as die gereformeerde wortels verreken word in die gebruik van die metafoor van gasvryheid vir die prediking.

\section{Aktualiteit van die metafoor}

\section{1 'n Vergete metafoor?}

Vir 'n groot deel van die Westerse kerk het gasvryheid as deug sedert die agttiende eeu in 'n sekere sin verlore geraak. Daarmee word bedoel dat dit as 'n morele deug op die agtergrond geskuif het en weinig aandag in teologiese diskoerse geniet het. Die kerk het steeds na die armes en weduwees omgesien, maar gasvryheid nie werklik as 'n bediening beskou nie. Daarom word vandag hoofsaaklik daarna verwys binne die toeriste-industrie as dienste wat deur hotelle en restaurante voorsien word. Calvyn het in sy tyd al die agteruitgang van klassieke gasvryheid betreur (Pohl, 1999:36).

In hierdie verband is dit ook interessant om te let op die verskuiwing in die lokaliteit van gasvryheid. In die Ou en Nuwe Testamente was gasvryheid gelokaliseer in die huishouding, in die Vroeë Kerk, in 'n versameling van huishoudings, in die vierde en vyfde eeu vind ' $n$ uitbreiding plaas na hostelle, hospitale, kloosters en in die Middeleeue was dit veral in die kloosters en sogenaamde "hospices" vir 
pelgrims waar gasvryheid beoefen is. Gedurende die reformasie en die aanbreek van die moderne era vind 'n mens dat die openbare dimensie van gasvryheid losgemaak is van die Christelike wortels aangesien die openbare lewe al meer gesekulariseerd geraak het (Pohl, 1999:39-58).

Belangrike veranderings in die laaste twee eeue het moderne vorms van gasvryheid verander en bemoeilik. Aktiwiteite wat vroeër deel van die huishouding was - werk, geloofsrituele, beskerming, opvoeding, siekesorg, bejaardesorg en vreemdelingsorg - is nou in hulle eie sfere en in aparte instellings gelokaliseer. Elkeen van hierdie sfere het ook hulle eie kulture, reëls en spesialiteite. Met verstedeliking en industrialisasie het die huishouding al kleiner en meer privaat geraak, 'n veilige vesting weg van die wêreld waarin min vreemdelinge toegelaat word. Privaatheid verhoog die risiko's wat verband hou met die aanbied van gasvryheid aan vreemdelinge, terwyl huishoudings oor die algmeen met probleme worstel soos onstabiliteit, niemand wat by die huis is nie, ensovoorts (Pohl, 1999:5758).

\subsection{Herwinning van hierdie metafoor}

Ten spyte van bogenoemde "beperkings" verbonde aan die gebruik van dié metafoor, is daar steeds groot potensiaal in die herwinning daarvan. Trouens, hierdie probleme dien juis as uitdaging om dié metafoor opnuut te ontgin.

Henry Nouwen (1975:66) skryf in hierdie verband: "If there is any concept worth restoring to its original depth and evocative potential, it is the concept of hospitality." Ons het reeds gesien dat Calvyn dieselfde oortuiging het. Pohl (1999:52) bied ook 'n interessante kykie op Calvyn se waardering vir gasvryheid teen die agtergrond van sy eie vlugtelingbestaan.

Volgens Pohl (1999:38) hou die toekoms van Christelike gasvryheid direk verband met die huislike en familielewe. Vir die herwinning van gasvryheid is dit noodsaaklik dat die huishouding én die gemeente as 't ware teruggewen moet word as die sentrale plek vir hierdie bediening. Dit is veral belangrik vir die prediking dat die huishouding en die kerk op 'n nuwe manier ook aan mekaar gebind moet word, sodat hierdie twee instellings as bondgenote kan saamwerk ter wille van die wêreld. 


\subsection{Aktualiteit vir die prediking}

Die gebruik van die metafoor van gasvryheid vir die prediking gaan oor veel meer as om bloot oor gasvryheid as deug te preek. Die metafoor wil ons help om vanuit 'n nuwe perspektief na die prediking te kyk om daardeur die vanselfsprekendheid van die bestaande te deurbreek.

Hendriks (1999:53) gebruik die metafoor van gasvryheid vir die hele gemeente. Dit wat hy daaroor bespreek, wil ek op die prediking toepas en uitbrei om daardeur ook die aktualiteit van die metafoor vir die preekaktiwiteite te beklemtoon. Hierdie artikel help ons om die prediking te sien as:

- 'n plek waar daar iets van die misterie van die Groot Gasheer geniet word nog voordat daar 'n woord gespreek is;

- 'n plek waar ook die arme, die verontregte, die wees en die weduwee welkom is en verniet iets kry om te eet en te drink;

- 'n plek waar die gaste die geleentheid kry om hulle eie verhale te vertel en na ander te luister; waar moontlikhede vir berading ontstaan; waar 'n mens saam in aksie kan kom, maar ook die geselligheid kan ervaar wat rus en ontspanning bring;

- 'n handeling waarin predikers poog om langs mense te kom staan, deur oop en gasvry te wees en uitnodigend te kommunikeer;

- 'n handeling waar daar nie gepoog word om mense te probeer "binnehou" nie, maar hulle eerder van die nodige (hemeneutiese) hulpmiddels voorsien om self keuses te kan maak en met blydskap daardie weg te volg;

- 'n handeling waarin die beeld wat van die prediker (gasheer) opgeroep word, verband hou met die bereidwilligheid om te dien en nie te heers of te domineer nie;

- feesgebeure wat geskied in die Gees van die Groot Gasheer.

In hierdie verband moet die prediking as 't ware as 'n aptytwekker vir die aangrypende visioen van Jesaja 25:6 dien: "Op hierdie berg gaan die Here die Almagtige 'n feesmaal gereed maak vir al die volke, 'n feesmaal met die beste om te eet en te drink, goeie kos en geurige wyn."

Verder is ek oortuig dat hierdie metafoor sinvol binne ons eie samelewing ontgin kan word. Dit doen 'n appèl op die verlange na 'n oop 
gemeenskap en het nie pretensies wat te hoog is nie. Dit is ' $n$ Bybelse en realistiese metafoor wat ons inderdaad kan help om met nuwe oë te kyk.

\section{In die gastehuis van die prediking}

\subsection{Die wêreld van die gaste}

Heelwat navorsing is reeds gedoen wat vir ons iets van die "wêreld van die gaste" help verstaan (vgl. Nash \& McLennan, 2001:3-39; Hendriks, 1999:25-36; Vos, 1996:197-204; Van der Ven, 1993:1731). Ons kyk net na enkele kenmerke van die wêreld waarin die gaste leef en werk en wat die implikasies daarvan vir die prediking inhou.

\subsection{1 'n Wêreld van sosiale differensiasie en 'n behoefte aan spiritualiteit, gesprek en religieuse ervaring}

In die werk van Nash en McLennan (2001) met die veelseggende titel, Church on Sunday, work on Monday: the challenge of fusing Christian values with business life, wys hulle dat daar 'n diepe behoefte aan spiritualiteit onder mense bestaan. Die probleem is dat hierdie behoefte dikwels gevul word met 'n tipe sekulêre spiritualiteit waarin na alles wat beskikbaar is gegryp word vir die vervulling van hierdie behoefte. Daarom hoor ons dikwels dat mense sê: "I am spiritual, but not religious".

Laasgenoemde word verder aangehelp deur die prosesse van sosiale differensiasie waarin die verskillende sektore van die samelewing, soos die politiek, ekonomie, wetenskap, sport en kerk, elkeen tot aparte wêrelde gegroei het. Elkeen van hierdie wêrelde het hulle eie waardes en doelwitte wat mekaar beïnvloed, maar ook onoorsigtelik en verwarrend kan raak. Die gevolg is dat 'n oorkoepelende waardesisteem ontbreek. Laasgenoemde roep die vraag na samehang en sin op (Hendriks, 1999:26).

In die "gastehuis van die prediking" moet ons bedag wees op hierdie behoefte aan spiritualiteit, religieuse ervaring en aan die groter samehang en sin van alles. Ons kan deur gasvry te wees mense uitnooi om 'n Bybelse visie te help ontwikkel. Deur narratiewe verbeelding kan ons in die prediking mense bekend stel aan die Bybelse verhale wat óns vorm (Eslinger, 1995:38). 


\subsection{2 'n Wêreld van individualisering en 'n behoefte aan gesprek en ontmoeting}

Dit is oorbekend dat ons in 'n hoogs individualistiese samelewing leef. Daaronder verstaan ons dat mense van vandag dikwels baie los funksioneer van die tradisionele verbande van gesin, kerk en buurt. Subjektiwiteit, selfstandigheid, mondigheid, en so meer is die kernbegrippe. Hierdie soort individualisering skep 'n behoefte aan informasie en aan plekke waar mense in vryheid idees kan uitruil. Plekke waar hulle dus gasvry ontvang word en nie in een van hulle rolle benader word nie, maar as mens, as unieke persoon, (vgl. Hendriks, 1999:32). In die "gastehuis van die prediking" is dit moontlik om hierdie gesprek en ontmoeting te inisieer.

\subsection{3 'n Wêreld van praktiese agnostisisme en 'n behoefte aan geloofservaring}

Dit is interessant dat die huidige religieuse situasie nie gekenmerk word deur mense se ontkenning van die bestaan van God nie, maar eerder deur onverskilligheid en onsekerheid daaroor. In agnostiese terme gestel: "Jy weet nie, jy kan nie weet nie en jy kan van niks seker wees nie". Saam met laasgenoemde is daar ook die groeiende behoefte aan "geloofservaring" (Hendriks, 1999:35).

'n Aantal dekades gelede het Karl Rahner (1966:22) reeds gesê:

De christen van morgen zal een 'mysticus' zijn, iemand die iets ervaren heeft, of hij zal niet meer zijn, omdat de spiritualiteit van morgen niet meer ... meegedragen wordt door eenstemmige, vanzelfsprekende overtuiging en religieuze praktijk van alle.

In hierdie verband gaan dit nie oor buitengewone ervarings wat net vir sekere ingewydes bedoel is nie. Dit gaan om gewone mense se ervaring van God in die alledaagse werklikheid, in 'n lied, 'n belydenis, 'n verhaal, 'n ontmoeting, 'n viering (Hendriks, 1999:35).

Die gastehuis van die prediking is die plek waar mense as 't ware "op die spoor van God kan kom"; 'n plek waar ervarings uitgeruil kan word en aanvaarding beleef word; waar die kern van gelowigwees beleef kan word deur gemeenskap met God, met mekaar en deur diens aan die wêreld. Dit bring ons by die Persoon oor wie dit ten diepste gaan. 


\subsection{Die Groot Gasheer}

Die Bybelse beeld van God as gasheer, soos die metafoor van gasvryheid, tref ons in sowel die Ou as die Nuwe Testament aan. Van die belangrikste teksgedeeltes is alreeds genoem. Ten einde die belang van God as die "Groot" gasheer vir die prediking uit te spel, skenk ons verder aan enkele aspekte aandag.

\subsubsection{God as Israel se Gasheer}

Die beeld van "God as Gasheer" vind ons van die begin van die Ou Testament af. Reeds met die skeppingsverhale lees ons van God se gasvryheid in die wyse waarop Hy aan mens en dier kos en verblyf voorsien (vgl. Gen. 1:30; Ps. 104:27; Job 38:39-41). Die hele tuinverhaal in Genesis 2 hou verband met God se voorsiening in die mense se behoeftes - 'n veilige en aangename plek om te lewe en te rus, kos en gemeenskap te geniet (vgl. Ryken, 1998:404-406). Ook in die uittogverhaal van Eksodus vind ons die gasvrye optrede van God in die wyse waarop die volk van Hom afhanklik is vir hulle oorlewing in die woestyn. God voorsien beskerming sowel as voedsel (vgl. Eks. 16 en 17; Ps. 78:19; 105:39-41).

Die gasvryheid van God word verder onderstreep deur die beskrywing van die tabernakel en later die tempel as "die Here se huis". Nadat die tempel voltooi is en ingewy word, hoor ons in Salomo se gebed die hartklop van God wat ook 'n plek vir die vreemdeling het binne die ruimte van aanbidding (vgl. 1 Kon. 8:41-43). Alhoewel God vry was om op enige plek teenwoordig te wees, het God belowe om in Israel se aanbidding op 'n besondere wyse teenwoordig te wees. Die klimaks van Ou-Testamentiese verwysings na gasvryheid vind ons in Psalm 23:5-6:

$U$ laat my by 'n feesmaal aansit ... U ontvang my soos 'n eregas, ek word oorlaai met hartlikheid. $U$ goedheid en liefde sal my lewe lank by my bly en ek sal tuis wees in die huis van die Here tot in lengte van dae.

\subsubsection{Jesus as Gasheer}

In die Nuwe Testament is Jesus by verskillende geleenthede die gasheer. Hy verander water in wyn om die feesviering voort te sit in Johannes 2:1-10. Twee keer het Hy die skares wonderbaarlik gevoed (vgl. Matt. 14:15-21; 15:32-38), en Hy vertel dat Hy self die brood vir die lewe is, die ware manna wat uit die hemel gestuur is (Joh. 6:30-51). Na sy opstanding vind ons die verhaal van Jesus op pad na Emmaus en die gebeure wat aan tafel afspeel (Luk. 24:13- 
35), terwyl ons in Johannes 21:9-14 lees hoe Jesus 'n maaltyd van brood en vis vir Petrus en die ander dissipels voorberei het.

\subsubsection{Enkele gevolgtrekkings}

Uit die Ou en die Nuwe Testament sou 'n paar gevolgtrekkings gemaak kon word oor die manier waarop God as Groot Gasheer aan die werk is. Gevolgtrekkings wat in 'n sekere sin as vertrekpunt dien in ons nadenke oor die gastehuis van die prediking, aangesien daar geen gastehuis bestaan sonder dié gasheer nie.

\section{- Die teenwoordigheid van dié Gasheer as gawe en belofte}

God se teenwoordigheid as Gasheer gee vir ons die grondrede vir die liturgie en prediking. Ons liturgiese handelinge (rituele met die preek as één so 'n ritueel) is daarom nie maar net 'n uitdrukking van hoe die méns (Israel en die Vroeë Kerk) dinge gesien het nie, maar hoe Gód die méns gesien het. In hierdie sin is die liturgie en prediking 'n gawe van die Groot Gasheer self, en die gawe van sy teenwoordigheid was en is beskikbaar aan almal wat Hy uitnooi. Aangesien God ook die vreemdelinge uitgenooi het, en dikwels self as vreemdeling gekom het, mag ons nie die vreemdelinge uitsluit nie (vgl. hieronder die bespreking oor die verskillende tipes vreemdelinge).

\section{- $\quad$ Die mistieke, misterieuse en paradoksale aard van die Gasheer se teenwoordigheid}

In albei testamente vind ons onverklaarbare en onbeskryfbare aspekte van die Groot Gasheer se teenwoordigheid. Ons sou baie tekste in hierdie verband kon opnoem, maar in Genesis 18, Hebreërs 13:2 (wat verwys na Gen. 18), Lukas 24 en Matteus 25 vind ons verhale van die mistieke en paradoksale aard van die Groot Gasheer se teenwoordigheid.

Deur gasvryheid te betoon word dit in hierdie verhale duidelik dat nie alleen engele gehuisves word nie, maar die lewende God self. In Genesis 18 is die gas by die deur niemand anders nie as God, vandaar die oproep in Hebreërs 13:2: "Moenie nalaat om gasvry te wees nie, want deur gasvry te wees, het sommige mense sonder dat hulle dit geweet het, engele as gaste gehuisves." In Lukas 24 is dit die vreemdeling op die pad (Jesus) wie se teenwoordigheid nie alleen vir hulle seën bring nie, maar ook nuwe moontlikhede oopbreek. Hierdie vreemdeling verwissel rolle aan tafel en word die Groot Gasheer, wat brood breek en seën. 
Dalk die aangrypendste teks in hierdie verband is Matteus 25:31-46. Wat dié teks so belangrik maak, is die ingrypende implikasies van die herkenning óf miskenning van die gas/vreemdeling voor die deur. Die moontlikheid dat Jesus self as gas aanklop in die gelaat van die ander/vreemdeling intensifiseer en verbreed ons begrip aangaande sorg en respek vir hulle wat maklik deur die samelewing misgekyk kan word (Pohl, 1999:67).

\section{- $\quad$ Die sakramentele aard van die Gasheer se teenwoordigheid}

Die manier waarop Israel en die Vroeë Kerk die mistieke en paradoksale teenwoordigheid van God as 't ware ontvang het, was deur middel van rituele. Rituele was 'n kombinasie van die Groot Gasheer se aktiwiteit en dit wat die gaste gedoen het wanneer hulle God se teenwoordigheid ervaar het.

Dit word in die verhaal van die Emmausgangers mooi geïllustreer. Nadat hulle saam aan tafel was, Jesus die brood gebreek (Nagmaal) en vir die gaste gegee het, het hulle oë oopgegaan en het hulle Hom herken. Dan reageer hulle soos volg: "Het ons hart nie warm geword toe Hy op die pad met ons gepraat en vir ons die Skrif uitgelê het nie?" (Luk. 24:32).

Hierin vind ons ook die klem op die rol van die preek as ritueel. Dit is Calvyn wat, in aansluiting by Augustinus, beklemtoon het dat die woorde van die prediker "tekens" is wat heenwys na die Groot Gasheer. In hierdie verband vergelyk Calvyn en Augustinus die woorde van die klein gasheer (die prediker) met die manier waarop die elemente van die Nagmaal by die Katolieke Kerk funksioneer. Soos die brood en die wyn deur die uitspreek van die priester se seën in die liggaam en bloed van Jesus verander, is dit die Groot Gasheer wat die woorde van die klein gasheer verander om as God se Woord by die oor van die gaste aan te kom (Leith, 1990:87).

\section{- Die uitbundige aard van die Groot Gasheer se gasvryheid}

Koenig (1985:26) wys op die uitbundige en oorvloedige aard van Jesus se gasvryheid. Dit is 'n kenmerk van Jesus se lewe en bediening en 'n manier om die nuwe wêreld (koninkryk) van die Groot Gasheer te begryp. Dit is veral die sentrale metafoor van die groot banket of maaltyd waarin laasgenoemde uitgedruk word (vgl. Luk. 14:15-24 en Matt. 22:1-10).

Die uitbundigheid van hierdie gebeure staan in skerp kontras met ons eie selfgesentreerde lewens. As gaste raak ons deel van die 
tafelgemeenskap deur die ritueel van die maaltyd. Die Groot Gasheer se vrygewigheid bring by ons 'n dankbare reaksie waarin ons ook gewillig raak om hierdie oorvloed met ander (die vreemdelinge) te deel. Diegene wat deur die geloof sien en glo, se lewe gaan dus deur vrygewigheid oop om ook aan die vreemdeling gasvryheid te bewys.

\subsection{In die gastehuis}

Met 'n beter begrip van die gasvryheid van die Groot Gasheer, moet aandag geskenk word aan die gebeure in die gastehuis self. In 'n sekere $\sin$ is daar reeds in die vorige afdeling aan aspekte daarvan aandag gegee. In hierdie afdeling word veral stilgestaan by die gaste, wie hulle is en wat hulle deelname beteken. Die feesvierings, liturgie en dies meer, kom op 'n ander plek aan die orde.

\subsubsection{Die essensie van die gebeure}

Hier sou gevra kon word: Waaroor gaan dit ten diepste in die gastehuis van die prediking? Hierop sou ons kon antwoord deur te sê: Dit gaan in essensie oor die inisiatief van die Groot Gasheer wat ons deur die stem van die klein gasheer uitnooi om aan die tafel in die gastehuis te kom aansit.

Deur die insiatief van God ontstaan 'n besondere gemeenskap wat ook deur ' $n$ ander Bybelse begrip koinonia saamgevat kan word. Dit is die begrip wat ook deur die Wêreldraad van Kerke gebruik word (vgl. Raiser, 1998). Hendriks (1999:37) gebruik ook hierdie begrip. Hendriks se samevatting van die begrip koinonia word gebruik, maar dit word telkens vertaal met die metafoor van gasvryheid. Ons sou kon sê dat die gebeure in die gastehuis verband hou met

- ons omgang met die Groot Gasheer, wat met ons persoonlike geloofslewe asook ons samekomste in die gastehuis (liturgie en prediking) te make het;

- ons gemeenskap met mekaar as gaste, wat te make het met 'n bepaalde relasie tussen die gaste, waarin die gaste na mekaar omsien en mekaar tot diens is; en

- ons diens aan die samelewing (vreemdelinge) deur woord en daad, wat te make het met 'n dubbele beweging van "uitgaan" na die samelewing, en ook om as gemeente van gaste jou oop te stel vir die deelname van die vreemdeling deur hom/haar "in te nooi". 
As samevatting sou 'n mens kon sê dat die sentrale begrip in die identiteitskonsepsie van die prediking as gastehuis, gasvryheid is, of anders vertaal, herbergsaamheid. Dit is nie 'n bykomende kenmerk nie, dit is die dominante kenmerk of karaktertrek wat die hele stelsel organiseer (Hendriks, 1999:56). Die opmerkings hierbo verteenwoordig die vier kenfunksies wat in teorieë oor gemeentes voorkom, naamlik leitourgia, kerugma, koinonia en diakonia (vgl. Burger \& Nell, 1999:203-260). Die metafoor van gasvryheid het twee verdere prominente kenmerke, naamlik dat die gaste sentraal staan en dat die gaste vryheid geniet.

\subsubsection{Die gaste staan sentraal}

Dit beteken onder andere dat die gemeente haarself vir die gaste, dus vir vreemdelinge oopstel. In hierdie verband is die Griekse woord filoxenia interessant. Dit beteken letterlik liefde vir die vreemdeling. 'n Gasvrye gemeente is dus 'n uitnodigende gemeente. Nie net is die deure oop vir die gaste nie, maar die lidmate is self ook oop en ontvanklik. Gaste en vreemdelinge word uitgenooi om plek in te neem in die hart van die gemeente, om aan die ronde tafel te sit en mee te doen aan die feesvierings deur die verhale van hulle eie lewe met mekaar te deel (Hendriks, 1999:58).

Cilliers (2002:143) beklemtoon, in aansluiting by Luther, dat die Woord van God nooit losgemaak kan word van die volk van God nie. Die gaste in die gastehuis is inderdaad die draers en beskermers van die waarheid (1 Tim. 3:15). Vergelyk ook die opmerkings van Barth in hierdie verband (Cilliers, 2002:146-147).

Dit beteken verder dat die gaste ook in mekáár se lewens gaste is. Daarvoor is 'n tweegesprek nodig waardeur vertroue gebou word. Gewoonlik geskied dit deur huisbesoek en kleingroepe, maar dit is ook in die preek moontlik deur ware dialogiese prediking. Nog 'n rede waarom die gaste sentraal staan, hou verband met die feit dat die lidmate van die gemeente nie die eienaars is van die ruimte of die kerkgebou nie. Die eienaar van hierdie herberg is Jesus Christus. In daardie sin is ons nie die primêre gashere of gasvroue nie, maar self gaste. Ons is Jesus se gaste wat deur Hom na die tafel uitgenooi word. Dit is wat die Emmausgangers ervaar het toe hulle die vreemdeling as gas genooi het, maar die rolle tydens die ete gewissel het en Hy self die gasheer geword het (vgl. Luk. 24:30).

In 'n meer omvattende sin is ons ook gaste deurdat ons self ook vreemdelinge en bywoners is (vgl. Lev. 25:23; 1 Pet. 2:11; Heb. 11:13). Dit is waar die begrip parochie vandaan kom. Par-oika bete- 
ken letterlik om in 'n vreemde land te bly. In hierdie sin dui parochie oorspronklik op die byeenkomste van die par-oikoi, wat die Grieks vir bywoners is, mense wat op weg is en 'n tydelike heenkome soek (Hendriks, 1999:60).

\subsubsection{Vryheid van die gaste}

Saam met die sentraliteit van die gaste word die vryheid van die gaste ook beklemtoon. Die gas word uitgenooi, maar nie gedwing onder valse voorwaardes na binne gelok of verlei nie. Gasvryheid is nie 'n middel tot 'n doel nie, maar 'n doel op sigself. Die gasheer en gasvrou laat die gas vry. Hierdie aksent op die vryheid van die gas is nie 'n hedendaagse buiging voor individualisme nie, maar die erkenning van 'n klassieke Bybels-teologiese waarde (Hendriks, 1999:65).

Dit is hierdie vryheid wat gedurende die Reformasie deur Luther en Calvyn herontdek is. Die reëls van die gastehuis moet dus hierdie vryheid dien. Alhoewel die gasheer/-vrou hulle nie aan die gaste opdwing nie, is hulle wel daar en laat hulle hulle teenwoordigheid geld. Nouwen haal Hendriks (1999:65) aan wanneer hy sê:

Als we werkelijk gastvrij willen zijn moeten we niet alleen vreemdelinge binnelaten, maar hem ook confronteren met onze ondubbelzinnige aanwezigheid, niet onszelf verbergen achter neutraliteit maar hem helder en duidelijk inzicht geven in onze ideën, meningen en manier van leven. Tussen iemand en niemand is geen werklijk gesprek mogelijk.

Vir die prediking is laasgenoemde van groot belang, aangesien dit ten diepste juis oor hierdie aanwesigheid en gesprek gaan.

\subsubsection{Wie is die gaste?}

Die gaste is sentraal en hulle is vry, maar wie is hierdie gaste? Die drie maniere waarop Keifert (1992:8-9) die term stranger (gas of vreemdeling) gebruik, kan help om 'n duideliker beeld van die gaste te kry:

- Die eerste groep gaste/vreemdelinge is hulle wat ons buite die gastehuis of gemeente aantref, die sogenaamde "outside strangers". Hulle is diegene wat dikwels anders lyk, aantrek en praat as die gemiddelde lidmaat van die gemeente. Hulle kan selfs deel wees van 'n ander klas, ras, ouderdom, geslag of lewensituasie as die sogenaamde insiders. Hierdie groep vorm dikwels die 
kleinste persentasie van die gaste wat op 'n Sondagoggend in die eredienste bymekaar kom.

- Die tweede groep gaste/vreemdelinge is die sogenaamde "inside strangers". Hulle vind ons iewers tussen die intieme binnekring van leierskap en "aktiewe gaste" in die gemeente en die "outside strangers". Om betekenisvol aan die gebeure in die gastehuis deel te neem, is daar dikwels 'n paar struikelblokke wat oorkom moet word. Hulle is dikwels die "passiewe gaste" eerder as aktiewe deelnemers aan die gebeure.

- Die derde manier waarop die begrip gas/vreemdeling gebruik word, het te make met die onverkleinbare verskille wat tussen twee mense binne enige interaksie met mekaar bestaan. Selfs tussen naby familie en vriende bestaan hierdie onverkleinbare verskille. In 'n sekere sin sou ons selfs kon sê dat hierdie verskille binne ons eie selfverstaan voorkom. In hierdie verband bly ons selfs vir onsself vreemdelinge.

Keifert (1992:9) wys hoedat die inside én outside strangers as 't ware "buite" gaan blý indien ons bly vashou aan twee vooronderstellings wat as sterk "onderstrome" deur ons kultuur vloei. Hy noem hierdie sogenaamde undercurrents die ideologie van intimiteit en individualisme. Volgens hom is daar weinig kans om die gaste in die gastehuis te laat welkom voel indien ons nie deeglik bewus is van die invloed wat hierdie onderstromings op die lewe in die gastehuis uitoefen nie. Die invloed van hierdie onderstromings lei maklik daartoe dat die gas of vreemdeling uitgesluit voel, selfs wanneer ons doodseker is dat ons hulle laat welkom voel.

Pohl (1999:85-103) gee 'n meer omvattende bespreking van die gas/vreemdeling onder die opskrif "the strangers in our midst" en noem onder andere die volgende groepe: "'relative' strangers and contemporary society, 'unknown' strangers and personal responses, 'risky' strangers and worried hosts, desperate strangers and hesitant welcome, the strangers nearest to us."

\subsubsection{Die rol van tyd}

In die gastehuis van die prediking speel tyd 'n sentrale rol omdat tyd orden en kwalifiseer. Vir Miskotte (aangehaal in Van der Velden, 1984:201) is die Sondag in hierdie verband van besondere belang. Sondag is die dag van die opstanding waarop die Opgestane die uitnodiging tot deelname in die hede rig. Dit gaan immers oor die teenwoordigheid en spreke van die Groot Gasheer. Hierdie spreke geskied nie direk nie, maar indirek deur die Woord. Dit het die ka- 
rakter van 'n gesprek waarin daar 'n verborge omgang tussen die Groot Gasheer, die klein gasheer en die gaste plaasvind.

Maar hierdie verstaan van die Sondag gaan nog verder terug. Gedurende die ballingskap, ná die vernietiging van Jerusalem en die tempel, het die sabbat en die viering daarvan al hoe belangriker begin word. Toe die tempel vernietig is, het die sabbat as 't ware 'n tempel in die tyd geword. Die sabbat het in hierdie verband 'n soort sakrament geword - die teken en die simbool van God se teenwoordigheid. Laasgenoemde was 'n nuwe ontwikkeling in die geskiedenis van Israel (vgl. Meyer, 2002:2).

\subsubsection{Die belang van lokaliteit}

Tesame met die belang van die dag en tyd lê die klem ook op lokaliteit. Aangesien die vroegste Christelike gemeenskappe hoofsaaklik uit Joodse Christene bestaan het, is dit belangrik om te let op die plekke waar hulle gasvryheid beleef het. Daar is drie onderskeie plekke waar hulle die gasvryheid van die Groot Gasheer geniet het (vgl. Keifert, 1992:63-71), naamlik in die tempel, in die huis en in die sinagoge.

\section{- Die tempel}

In die tyd van Jesus en Paulus was die tempel 'n openbare plek waar die vreemdeling aan gemeenskaplike rituele kon deelneem. Die lewe en bediening van Jesus is op verskillende plekke aan die tempel gekoppel. Alhoewel daar ook kritiek teen die tempel is en Jesus self die offerpraktyk vervang, bly die voortgaande invloed daarvan as openbare aanbiddingsplek belangrik.

\section{- $\quad$ Die huis}

In die opkomende Christelike gemeentetjies was die sogenaamde huiskerke die primêre plek van aanbidding. Aan die tafels was daar 'n plek vir die vreemdeling. Die huiskerke het gegroei uit die Joodse tradisie waar daar, sedert die vernietiging van die tempel, gereeld in huise bymekaargekom is.

\section{- $\quad$ Die sinagoge}

Die grootste deel van die vroeg-Christelike eredienste is net so uit die sinagoge-erediens oorgeneem. Die vroegste sendelinge (soos Paulus) het eerste na die sinagoge gegaan vir aanvanklike kontak. Alhoewel die sinagoge later vir Christene gesluit is, het dit 'n sterk invloed op die aanbiddings- en gemeenskapspraktyke van die vroeg-Christelike kerk uitgeoefen. Die openbare en oop karakter van 
die sinagoges sien ons in die wyse waarop Jesus, Paulus en andere as rondreisende predikers dikwels genooi is om uit die Skrif te lees en kommentaar daarop te lewer. Ons lees selfs dat dit Jesus se "gewoonte" was om na die sinagoge te gaan (vgl. Luk. 4:16-30).

Dit is duidelik dat al drie hierdie lokaliteite plek gehad het vir die gas/vreemdeling en dat die gastehuis van die prediking, soos ons dit vandag ken, se wortels in die lokaliteite te vinde is. Dingemans (aangehaal in Hendriks, 1999:64) vat die kom en gaan in die gastehuis van die prediking goed saam as hy sê die kerk is "geen huis meer om in te wonen - maar een herberg waarin we af en toe vertoeven, omdat we in onze moderne sameleving vootdurend op weg zijn".

\subsection{7 'n Behoefte aan tafelgesprekke}

In die gastehuis van die prediking is die gaste nie alleen welkom nie, maar lewer hulle ook 'n wesenlike bydrae tot die preek- en feesgebeure. Daarom is daar inderdaad sprake van "in-stemming" volgens Cilliers (2002:143) - instemming van die gaste in die sin dat hulle nie slegs passiewe ontvangers is nie, maar ook aktiewe deelnemers. Trouens, dit is juis Jesus se optrede wat op verskillende plekke (Joh. 13; Luk. 24) wys hoe maklik die rolle van gas en gasheer omgeruil kan word.

'n Waardevolle bydrae is die benadering van McClure (1995) wat van die "roundtable pulpit" praat, en dit verder uitbrei deur daarop te wys dat dit rondom hierdie ronde tafel is waar leierskap en prediking in die gemeente ontmoet. Die preekstoel kry hier as 't ware die vorm van 'n ronde tafel en om dié tafel is dit belangrik om seker te maak dat daar plek vir die gas/vreemdeling is en dat die verskeidenheid so groot as moontlik moet wees. Preekwerksgroepe is daarom onmisbaar as die gasheer/-vrou wil seker maak dat die tafelgesprekke nie 'n eenrigtingverkeer raak nie. Sodoende is die gemeente van gaste inderdaad die draers van die waarheid.

\subsection{Die klein gasheer/gasvrou}

\subsubsection{Primus inter pares}

Dingemans (1991:14) praat in sy omvattende homiletiese werk van die prediker "als hoorder onder de hoorders". Daarmee beklemtoon hy dat die prediker as gasheer/-vrou nie in die eerste plek die "gesaghebbende uitlegger" van die Skrif is of die amptelike verkondiger van die heil nie, maar dat hulle as primus inter pares die woorde van die Groot Gasheer op presies dieselfde wyse as die gaste hoor. As 
eerste hoorder, wat hom/haar beroepsmatig met die Bybel en die tradisie besig hou, fasiliteer hy/sy die gesprek in die gastehuis.

Hierdie invalshoek wat werk met die gesprekskarakter tussen die gaste, die gasheer/-vrou, die tradisie/Skrif waar saam geluister word na die woorde van die Groot Gasheer, is deur en deur 'n hermeneutiese benadering. Dit vra interpretasie, uitleg, gesprek en nog meer waarby die gaste voortdurend betrokke is.

\subsubsection{Meerdere vorme van gasheer/-vrou}

McClure (1995:25-29) in aansluiting by Koenig (1985) wys hoe die rol van gasheer/-vrou meerdere vorme in die Vroeë Kerk aangeneem het. Hulle onderskei tussen die rondgaande charismatiese profete wat deur gashere/-vroue ontvang is. Maar dikwels het hierdie rondgaande profete vasgesteek ("taken up residence") en dus self die gashere/-vroue vir ander geword. Hierdie gashere/-vroue het die aard van charismatiese outoriteit verstaan en het die charismatiese individue nie toegelaat om as 't ware 'n voortydige afsluiting van Christelike waarhede aan te kondig nie (die kenmerk van fundamentalisme). Die gasheer/-vrou het dit reggekry deur die boodskappe of "openbarings" van die charismatiese individue in gesprek met die lede van die gemeenskap te bring - lede wat elkeen verskillende gawes ontvang het. Dit het hulle gedoen deur voortdurend mense wat daarop aanspraak gemaak het dat hulle 'n boodskap het (insigte in die aard van die Christelike evangelie) binne én buite die gemeenskap, uit te nooi tot gesprek met mekaar.

So wys hulle dat die Vroeë Kerk plek gehad het vir die dinamiese interaksie tussen charismatiese én tradisionele outoriteit wat by gasvryheid betrokke was. Daar was ook nie 'n hiërargie tussen hierdie twee vorme nie. Paulus se charismatiese outoriteit het nie hoër status gehad as dié van sy verskillende gashere nie. Paulus en die leiers van die huiskerke het dus 'n "bipolêre outoriteit" gehad waarin albei aan die opbou van die geloofsgemeenskap meegewerk het.

\subsubsection{Meerdere tafels in die gastehuis}

Die ronde tafel van onderskeiding in die preekgesprek en die tafel waar die Here ons geestelik voed, staan as 't ware langs mekaar. Trouens, dit kan dieselfde tafel wees wat net op verskillende tye vir verskillende doeleindes gebruik word. Die feit bly dat die "tafel" in die hart van Christelike gasvryheid staan. 
'n Deel van die gasheer/-vrou se taak is om hierdie twee aktiwiteite ook so na as moontlik aan mekaar te hou. McClure (1995:29) merk op:

As host at this table, the preacher is the steward of both the story of Christ and the tradition of the community. The preacher sees to it that all conversations and sacramental actions are centered on the saving work of Jesus Christ and on the mission of the church. Hosting, therefore, is both a liturgical and ecclesial act in which all are welcomed to the pulpit-table of Jesus Christ.

\section{Slot}

Ons het aan die begin gesien dat metafore met paradokse werk, waar die spanning in 'n metafoor terselfdertyd bevestig én ontken dat iets die geval is. In die bespreking het dit duidelik geword dat ons met die metafoor "in die gastehuis van die prediking" voortdurend binne hierdie spanningsveld beweeg. Die fout wat nie gemaak moet word nie, is om te poog om hierdie spanning te probeer ophef, deur oor te hel na een van die pole van die metafoor. Die gevaar is dan dat ons nie slegs in dualisme verval nie, maar dat die kreatiwiteit waarna ons in die prediking soek, ook verlore kan raak.

As gashere en gasvroue is predikers saam met die gaste nie alleen luisterend op soek na die misterievolle stem van die Groot Gasheer nie, hulle het ook 'n verdere verantwoordelikheid. Hulle is rentmeesters van die verhaal van Christus en die tradisie. Daarom moet hulle toesien dat die gesprekke en sakramentele handelinge om die tafel 'n bepaalde fokus kry op die verlossende werk van Jesus Christus. Jesus Christus staan dikwels by die deur en klop en maak sy opwagting in die gelaat van die vreemdeling, gereed om self die Gasheer te word.

\section{Geraadpleegde bronne}

BURGER, C.W. 2001. Ons weet aan wie ons behoort: nuut gedink oor ons gereformeerde tradisie. Wellington: Lux Verbi.BM.

BURGER, C.W. \& NELL, I.A., reds. 2002. Draers van die waarheid: NuweTestamentiese visies vir die gemeente. Stellenbosch: Buvton. (Gemeente en bediening, 7.)

CHILDERS, J. 1998. Performing the Word: preaching as theatre. Nashville: Abingdon.

CILLIERS, J.H. 2002. Die geheim van die prediking: in stemming met die gemeente. Hervormde teologiese studies, 58(1):143-156.

CILLIERS, J.H. 2004. Die lewende stem van die evangelie: nuut gedink oor die basiese beginsels van prediking. Stellenbosch: Sun Media. 
DINGEMANS, G.D.J. 1991. Als hoorder onder de hoorders: een hermeneutische homiletiek. Kampen: Kok.

ENGEMANN, W. 2001. On man's re-entry into his future: the sermon as creative act. Lesing tydens die Internasionale Homiletiese Werkgemeenskap. (Ongepubliseerd.)

ESLINGER, R.L. 1995. Narrative imagination: preaching the worlds that shape us. Minneapolis: Fortress.

HENDRIKS, J. 1999. Gemeente als herberg: een concrete utopie. Kampen: Kok.

HILKERT, M.C. 1997. Naming grace: preaching and the sacramental imagination. New York: Continuum.

KEIFERT, P. 1992. Welcoming the stranger: a public theology of worship and evangelism. Minneapolis: Fortress.

KOENIG, J. 1985. New Testament hospitality: partnerships with strangers as promise and mission. Philadelphia: Fortress.

LEITH, J.H. 1990. From generation to generation. Louisville: Westminster.

LONG, T.G. 1989. The witness of preaching. Louisville: Westminster.

LOWRY, E.L. 1997. The sermon: dancing the edge of mystery. Nashville: Abingdon.

MCCLURE, J.S. 1995. The roundtable pulpit: where leadership and preaching meet. Nashville: Abingdon.

MEYER, O.S. 2002. Aspekte in verband met die geskiedenis van die prediking. Voordrag by Buvton se Heroriëntasiekursus vir Predikante. (Ongepubliseerd.)

NASH, L. \& MCLENNAN, S. 2001. Church on Sunday, work on Monday: the challenges of fusing Christian values with business life. San Francisco: Jossey Bass.

NOUWEN, H. 1975. Reaching out: the three movements of the spiritual life. New York: Doubleday.

OSMER, R. 2008. Practical theology: an introduction. Grand Rapids: Eerdmans.

POHL, C. 1999. Making room: hospitality as a Christian tradition. Grand Rapids: Eerdmans.

RAHNER, K. 1966. Schriften zur Theologie. TI. 7. Einsiedeln: Benziger.

RAISER, K. 1998. Een kerk te zijn op aarde: een toekomsperspectief. Baarn: Ten Have.

RICOEUR, P. 1979. Naming God. Union seminary quarterly review, 34(4):1527.

ROSSOUW, J. 2002. Geloofskrisis: nie net ons gode het voete van klei nie. Die Burger: 12, 17 Okt.

RYKEN, L., ed. 1998. Dictionary of Biblical imagery: an encyclopedic exploration of the images, symbols, motifs, metaphors, figures of speech and literary patterns of the Bible. Downers Grove: InterVarsity.

VAN DER VELDEN, M.J.G. 1984. K.H. Miskotte als prediker: een homiletische onderzoek. 's-Gravenhage: Boekencentrum.

VAN DER VEN, J.A. 1993. Ecclesiologie in context: handboek praktische theologie. Kampen: Kok.

VOS, C.J.A. 1996. Die volheid daarvan. Deel 1 en 2. Homiletiek uit 'n hermeneuties-kommunikatiewe perspektief. Pretoria: RGN.

VOS, C.J.A. 2002. Beeldende taal: Bybel en poësie. Hervormde teologiese studies, 58(1):157-171. 
VOSLOO, R.R. 2002. Gasvryheid. (In Burger, C.W. \& Nell, I.A. reds. Draers van die waarheid: Nuwe-Testamentiese visies vir die gemeente. Stellenbosch: Buvton. p. 305-306.) (Gemeente en bediening, 7.)

VOSLOO, R.R. 2003. Public morality and the need for an ethos of hospitality. Scriptura, 82:63-71.

VOSLOO, R.R. 2006. Engele as gaste? In gesprek ... oor gasvryheid teenoor die ander. Wellington: Lux Verbi.BM.

WAINWRIGHT G. 1991. Renewing worship: the recovery of classical patterns. Theology today, 48(1):45-55.

\section{Kernbegrippe:}

gasvryheid

metafoor

prediking

vernuwing

\section{Key concepts:}

hospitality

metaphor

preaching

renewal 